\title{
Staged Otherness in American Academia. A Reading
}

\author{
Andrea Zittlau \\ University of Rostock, Germany
}

\begin{abstract}
In the American academic tradition, the freak show as a research topic appeared in the late 1970s, focusing on othered bodies and popular culture, considered revolutionary at the time. This article looks at the history of the discourses staged otherness provoked in the American context. While it was launched together with other discussions of othering - such as 'the ethnic other', which eventually led to the field of postcolonial studies - otherness based on physical difference led to discussions that established a perception of the freak show as an American phenomenon. Scholars like Leslie Fiedler used the othered body to cope with personal crisis, while Edward Said criticized Western European and American forms of colonial thinking. However, physical otherness seduced academics to argue along the dichotomies of self and other to eventually position the self. This article looks at this development historically, involving psychoanalysis, postcolonial studies, literary criticism, and popular culture, to question the American element of the freak show and encourage a rewriting of its cultural significance.
\end{abstract}

Keywords: freak show, postcolonialism, disability studies, academic history, American Studies

In his by now famous 1932 film Freaks, Tod Browning tells a thrilling story of love and betrayal situated within a circus community. The main characters, sideshow performers in the film as in real life, battle the cunning murder plan of the star and normative beauty to marry and poison her admirer for his money. The film appeared at a time when freak shows disappeared as a form of entertainment. While the $19^{\text {th }}$ century experienced an extreme rise of entertainment culture due to what Thorstein Veblen has termed the new leisure class (VEBLEN 1899), new technologies such as the cinema, as well as the political shift in Europe, reduced the interest in circus performances and carnival attractions radically.

While one could have assumed that a move onto the screen would ensure the continuity of the luring success of the freak show, Tod Browning's film fundamentally flopped. Based on the short story "Spurs" by Tod Robbins (RoBBINs 1923), Freaks does not reproduce the show acts people knew from the fairs but presented a story set in the community of performers, thus portraying them as people with lives, perhaps the most shocking revelation for the audiences. The film ran only for a brief period and several cuts had been made in hopes of meeting the tastes of mainstream audiences (who 
had enjoyed the freak shows before). Nevertheless, it marked the end of Browning's career and was officially banned from cinemas in the United Kingdom (where the rating board felt that the film exploited people with deformities), or simply not shown at all (as in many movie theaters in the United States) (Hawkins 1996). In the 1960s, it made its reappearance as a cult film and has embraced that status ever since. Interestingly enough, the gap between the first screening of Freaks and the rediscovery of the film also marks the public discourse about so-called freak shows. After their vivid existence in popular culture, they disappeared from the public radar until academia rediscovered them, shaping significantly the newly introduced discipline of Disability Studies.

This essay will provide a history of freak shows as an academic topic, with a particular focus on literature produced in North America. I will look at the emergence of the topic of staged otherness in American scholarship and employ a meta-perspective that allows us to investigate larger issues behind the inquiry of the othered body to think about useful ways to investigate Central and Eastern European staged otherness differently. I believe there is a need for differentiation, not only because the place is geographically different but also our current time of investigation is different. When I co-edited the volume on continental European freak shows in 2012 (together with Anna Kérchy), we wanted to call attention to the fact that the exhibition of othered bodies for entertainment purposes is not solely an American phenomenon; in fact, transnational dimensions are always evident (KÉRCHY - ZitTLAU 2012). However, my article here seeks to explore how freak shows have been discussed as being American throughout the $20^{\text {th }}$ century in order to help look for connections to Eastern and Central European examples, as well as to understand academic discussions in the context of their time and approach the phenomenon from today's geographically different position. While issues of identity in connection to disability have become a way to approach the shows in North America, I wonder whether looking at the same phenomena (as far as it can be discussed as the same) in a different context may produce a new theory and methodology and conclusively new insights into cultural visions of the human body.

Furthermore, the study of more geographically dispersed cases would help us understand why othered bodies are, as Margrit Shildrick notices, 'transhistorically' (and I would add transculturally, transnationally) 'disturbing' (SHILDRICK 2009:45). The term 'othered bodies' is important to me, although I will diverge from it at times throughout my essay when I refer to other sources or when other terms might be more fitting in the context. Most of the time, I will speak of performers, because the people that are subjects of the literature I discuss performed in freak shows. Although the term freak show is problematic, I use it because it was used most commonly. Originally, the term described people with physical deformities derogatively, excluding them from society by their appearance, marking them as curiosities (GARLAND-THOMSON 1996:4). By making clear that the people in sideshows performed acts and were not simply exposed 'freaks of nature', my use of the term should be obvious.

The term 'othered bodies' implies that these bodies are not different by some natural setting but made to represent difference, which is not to say, of course, that we have no variety of shapes and conditions in the human nature, but it takes away the agency of performance. However, the concept of staged otherness points out that there are bodies, people, that were constructed and presented as other in theatrical ways, and I see it as our continuous responsibility to uncover the constructions and dynamics of such staging. 


\section{THE 1970S - OF POPULAR ENCYCLOPEDIAS AND ACADEMIC GROUNDWORK}

In the late $19^{\text {th }}$ and early $20^{\text {th }}$ century, freak show performers had their regular appearance in medical literature. The renowned German physician Rudolf Virchow, for example, regularly invited celebrities such as Chang and Eng to the Berlin Society for Anthropology, Ethnology and Prehistory, where he conducted medical exams and published his findings, often using the pamphlet performance narrative (ZITTLAU 2017). These medical articles continued a discourse of monstrosity in which the body of the performer, the focus of the scientific investigation, was pathologized. The war years of the early $20^{\text {th }}$ century disrupted the medical research because the shows lost their popularity and freak show performers were persecuted by the fascist regime, thus they were no longer voluntarily available for medical examination.

While Europe struggled to rebuild its former structures after World War II, in the United States, a growing consciousness towards representation and identity rose out of the crisis. It is the era of the Civil Rights movement and the Stonewall riots, the growing protest against the Vietnam War, the assassination of John F. Kennedy (1963), and the Watergate Scandal in 1974. On the other side of the ocean, 32 African countries became politically independent, marking the end of the European empire. Academically, the field of Cultural Studies emerged in Great Britain, paving the way for fields of inquiry such as Disability Studies. The emergence of Cultural Studies is also important because it developed methodologies to look at forms of representation, thus developing an analytical understanding and the tools to deconstruct phenomena from the sphere of popular culture such as the freak show.

After disappearing as a phenomenon of popular culture, the freak show first reentered a semi-journalistic discourse before moving on to the scholarly level. Because there were hardly any freak show performers left (SCHEUGL 1974:20), people published their collections of cartes-de-visite often in form of encyclopedias featuring the biographies of the performers as narrated on the pamphlets that were part of the show (and the collections). This coincides with the surfacing of the film Freaks. In memory theory, this marks the transition from personal (communicative) memory into collective (cultural) memory. ${ }^{1}$ The fascination now focused on the image in form of a photograph rather than the performance act that used to be crucial to the staging of freaks. The entire phenomenon was understood as history, thus worthy of research as a means of preservation. Therefore, the first publications lament the loss of their childhood entertainment (DRIMMER 1973:415) and seek to hold on to the memories by publishing the material they had collected.

Show masters such as Phineas Taylor Barnum (1810-1891) made sure that enough material of their shows existed in the archives to outlive them and guarantee their immortality. Barnum is considered one of the most successful entrepreneurs whose touring shows, the American Museum, and his circus attracted millions of visitors because he aggressively marketed his shows and made the entrance fees cheap enough for the general working population to afford it. Many freak show celebrities performed at

1 For an elaboration of the concepts of collective and communicative memory, see the works by Jan and Aleida Assmann (Assman - Assman 1992). 
least once in their lifetime in a facility run by the Barnum management. Due to excessive promotional material that Barnum was able to print and spread, the records of his shows are preserved in several archives across the United States (COOK 2005). Since those archives did not face destruction like their European counterparts did during the war years at the beginning of the $20^{\text {th }}$ century, the material was and continues to be available to scholars and researchers. ${ }^{2}$ This availability may have provoked the focus on the United States (and P. T. Barnum) in literature about othered bodies, popular and scholarly.

An example of a non-academic popular book is Frederick Drimmer's Very Special People (1973). It included a middle section called "A Photographic Introduction" which featured the prints of cartes-de-visite, photographs or postcards with portraits of the performers that were popular souvenirs and often ended up in family photo albums. Drimmer wrote several books that tend to explore the macabre in dense sensationalist ways (such as a book about people 'captured by Indians' and executions in America). By focusing on othered bodies, he clearly situates the topic within the framework of lurid expectations. Drimmer, who had been a freak show visitor in his youth, arranges the material he gathered from the archives in the tradition of medical textbooks that deal with malformation, thus categorizing, for example, conjoined twins ("Chained for Life") or "Little People" and people that even in his system defy any taxonomical category (such as Julia Pastrana - more about shows of Pastrana in Warsaw, see KoPANIA in the present volume). ${ }^{3}$ He presents a sketch of the celebrities' lives as narrated in the sources available to Drimmer (such as pamphlets, newspaper articles, show materials). As such, the book follows a tradition that blurs medical accounts with the sensational presentation at the shows, both of which no longer existed on the scale they used to. In many ways, these encyclopedic accounts replaced the shows with a slight shift in the narrative. While previously the performers had enacted the fictional stories of fantasy worlds, such as the wild jungles of Africa or the ancient Aztec civilizations, publications like Drimmer's located them in the fantasy world of the past. Both such worlds carefully balance the actual reference to place and time with exoticized narratives of the other.

The United States was not the only country that had a market for books relating to freak show performers. In 1974, a year after Drimmer's, Hans Scheugl's book Show Freaks and Monsters was published in Germany. Scheugl, an Austrian filmmaker and author, uses the Adanos collection, a private collection that is now housed in the Prater Museum (which originally was a private collection as well) situated in Austria's capital Vienna, to illustrate a cultural history of the freak show. Félix Adanos (1905-1991), a famous juggler, collected everything he could find about show freaks, and categorized this material according to the show categories of the performers that traditionally resembled medical categories of deformity (e.g., bearded women, conjoined twins). Like

2 The archive of the Tierpark Hagenbeck in the city of Hamburg (Germany), for example, a popular entertainment facility famous for its ethnic shows, burnt down during a bombing in World War II. Only a few documents and promotional materials were saved (personal conversation with Hilke Thode-Arora, whose 1989 book on the Hagenbeck shows, Für fünfzig Pfennig um die Welt, is based on the available material from the archive; THODE-ARORA 1989).

3 A popular and widespread medical textbook that engraved the categories of unusual bodies is Anomalies and Curiosities of Medicine by George Gould and Walter Pyle, which was quoted from in the early years of the twentieth century. It also vividly reveals the connections of popular entertainment forms, such as the freak show, and medical science (GOULD - PyLE 1896). 
Drimmer's book, Scheugl's publication does not come from a place of scholarship. $\mathrm{He}$ does not want to study the collection of photographs and pamphlets; neither does he look for facts and information beyond the mostly promotional material that is in the Adanos archive. Instead, his book is framed as an attempt to "give back the innocence to the freaks" (SCHEUGL 1974:5, my translation) and to tell their story and history without prejudice. It comes from a place of pity and compassion, thus it also includes a page with an empty frame with the caption 'freak' and asks the reader to insert her/ his picture. Drimmer's book begins similarly with an anecdote of his daughter's dream after a visit to the archives to collect freak show material. In her dream, she was without arms and humiliated by staring crowds. But "I am you" (DrIMMER 1973:8), she claims, and Drimmer continues to write that "They [freak show performers] have always wanted to be treated as equals by their fellows" (DRIMMER 1973:8). While both authors express the wish to (re)install dignity for the performers, they cater to the same freak show sensationalism that they criticize. ${ }^{4}$

Scheugl's focus, however, and material is from Europe and includes information about the American show business from a European perspective in which, for example, show contracts were critically evaluated. He mentions an article in a German magazine called Der Artist that reported that artists had to commit to work in the service industry after their show on stage. He looks at the wider context of the exhibition of humans for human entertainment and discusses the rise of the sciences such as medicine and early capitalism in that context. His book also mentions the tension between show business and beggars and asks the reader to question the concept of the freak accompanying this section of the book with photographs of saluting Nazis. On the one hand, Scheugl seems to insist that we are all freaks (indicated by the empty picture frame), while, on the other hand, freaks (monsters) exist as the evil other (the Nazi example).

Fascist Europe does not only serve as a counter-productive example to question the term 'freak'. It is also part of the actual history of the disappearance of the freak show. In 1933, Major Dole, an American dwarf performer, protested against what he made sound like a dwarf performer invasion from Europe. Scheugl quotes Dole saying, "We are about 60 real dwarfs in our country and over 40 of them are unemployed. We are threatened by the immigration of dwarfs who are going to offer their services cheaper" (SCHEUGL 1973:20). Freak show performers were fleeing Europe if they could afford to do so in wise anticipation of what was to come. In 1937, the newspaper The Bremer Nachrichten (October 3 issue) includes an article clearly saying that the economy cannot support all showmen in Germany, thus a selection has to be made. The first to disappear are those exposing their disabilities - they had to enroll in the Reichsbund für Körperbehinderte, where most of them met the fate of the euthanasia program. Only so-called dwarfs and giants were still permitted to perform because they confirmed traditional folktales that were promoted by the Nazis. ${ }^{5}$

${ }_{4}$ Those popular books listing freak show performers in encyclopedic fashion did not go out of print. A recent example is a 2005 book by Marc Hartzman (HARTZMAN 2005).

5 An account of a family of little people in the death camps of World War II has been provided by Yehuda Koren and Eilat Negev (KoREN - Negev 2005). A good historical overview of the Euthanasia program during the fascist regime is provided by Ernst Klee (2010). However, nothing has been published focusing specifically on the fate of freak show performers during National Socialism. 
Germany's war history remains an almost invisible component of Scheugl's book and yet its presence makes the discussion of the freak show performers a political one. While he does not see the ways of othering that he uncritically borrows from the freak shows, he uses the book to elaborate on a history of exploitation (the exploitation of people with disabilities for show purposes) and capitalism. Thus, his book, unlike Drimmer's, provides a historical context to the material.

Published in 1976, Richard Altick's book The Shows of London: A Panoramic History of Exhibitions, 1699-1862 marks the transition to the scholarly sphere. In it, the literary scholar specialized in Victorian England examines the cultures of exhibition from the post-Renaissance to the $19^{\text {th }}$ century. He looks at the influential scheme of curiosity cabinets as an origin to exhibition modes that singled out the extraordinary, humans, animals, or objects. Altick did not look at curio categories; rather, he analyzed modes of display such as the diorama or the panorama and followed the exhibition of people especially in the royal court. His book continues to be an extremely valuable historical source for its chronological historical narrative that reveals the shift in technology and politics but understands the staging of othered bodies as embedded in Victorian culture. ${ }^{6}$

The actual breakthrough in scholarly literature discussing othered bodies came with Edward Said who helped to pave the way for what became known as Postcolonial Studies, and Leslie Fiedler whose work on freak shows arguably led to the field of Disability Studies. Like Altick, both are literary scholars whose books on the topic of human enfreakment were published in the very same year - in 1978: Orientalism and Freaks: Myths and Images of the Secret Self. Said and Fiedler are both privileged men writing from prestigious universities (University of Columbia and University of Buffalo, respectively) and both claim an outsider's perspective: Said due to his Palestinian and Fiedler to his Jewish heritage, as well as their experiences of being mocked and excluded during their childhood and youth.

Said analyzes colonial literature (such as by Joseph Conrad) and its romanticized representation of the Middle East (the so-called Orient in these texts). He discusses how the exoticizing assumptions are used to present the Orient as primitive and other compared to the Western world, and as such to ensure forms of oppression. To him, the systematic othering helped the colonial forces in their quest for domination. "[N]either the term Orient nor the concept of the West has any ontological stability", observes Said (SAID 1978:XVIII). To him the othered body shifts in time, space, and shape like a hallucination in the desert.

Said contributed fundamentally to the establishment of the field of Postcolonial Studies with Orientalism. ${ }^{7}$ For the purpose of this article, it is important to acknowledge that Said illustrated the dynamics of the Western divide between Orient and Occident.

${ }^{6}$ Other, more recent, books focusing on the freak show and the role of the freak performer in Victorian England have been written by Nadja Durbach (2009), Marlene Tromp (2008), and Helen Davies (2015). Because I focus particularly on the American development of the topic in academia, I will not discuss these books, but they fit smoothly into the history that I am presenting. They all appear more than a decade after disability studies have been established and the topic of 'freakery' had become acceptable in academia.

7 Said was only preceded by the Algerian-French psychoanalyst Frantz Fanon whose books such as Wretched of the Earth (1961 in French and 1963 in English) likewise contributed to the establishing of Postcolonial Studies and had been published more than a decade prior to Said (FANON 1963). 
This polar thinking that is, after all, a construct between self and other is also evident in all discussions of the freak show. Moreover, the freak show itself combined the motifs of physical deformity with discourses of the exotic other. Not only were many performance acts based on a far away and 'primitive' location (such as the What is it act or the Aztec children act), even more so, performers from distant locations with visible physical differences were presented alongside freaks but also in specialized shows called ethnic shows. These two forms of staging otherness are tightly connected, as is the academic discourse referring to them. Yet, in contrast to Said who approaches the issue of othering in the broader context of national and collective identity formations, Fiedler encounters the individual dimensions of othering. He clearly struggled in writing Myth and Images of the Secret Self (already having established an academic career with Love and Death in the American Novel published in 1960, a text that looks at the relationship between the American and the European novel), explaining that he intended an intimate and very personal exploration of his inner self:

\footnotetext{
"What monsters men have needed to believe in they have created for themselves in words and pictures when they could not discover them in nature. And it is with that psychic need, then, that we should begin; seeking prototypes neither in history or anthropology, nor in embryology or teratology, but in depth psychology, which deals with our basic uncertainty about the limits of our bodies and egos" (FIEDLER 1978:27).
}

Fiedler writes a cultural history of the representations of what he calls freaks, seeking the origin and purpose of his own fascination in (mainly Greek) mythology. The freak show performers and their bodies become metaphors that illustrate the process of othering in order to understand the self. In this approach, it makes sense to use the established system of freak categories (such as dwarfs and giants) because Fiedler treats them more like mythical characters than actual people and writes a history of cultural narratives in which they appear. Fiedler reflects on the problem of his sources and the fact that he simply cannot get a grasp of the performers' real life experience. In reference to Anna Swann, the Nova Scotia Giantess, Fielder writes: "Attempting to retell her story, I am baffled by the fact that, like earlier accounts, mine does not transcend the appeal of a newspaper 'human interest' article" (FIEDLER 1978:117). However, he does not make an attempt to escape the sensationalist route.

His book is a personal account, not a work with wider political interests like Said's who writes in a preface to a new edition of Orientalism: "I would like to believe that Orientalism has had a place in the long and often interrupted road to human freedom" (SAID 2003:xxx). Instead, Fiedler discusses every example in relation to himself as he tries to feel the pain of his mythical and real life characters, a pain that he relates to his own. His book finishes with the mutant in contemporary popular culture that includes comic strips (such as Legion of the Charlies; FIEDLER 1978:326) and science fiction novels (e.g., by Robert Heinlein, FIEDLER 1978:325), which was not the academic mainstream at the time. With his framework of Greek mythology and popular fiction, Fiedler clearly locates the freak within the cultural imagination and the freak show performers as its (profitable) embodiment. 


\section{THE 1980S - SHIFTING FROM MYTH TO DISABILITY}

The previously discussed works approach the freak show based on fiction (therefore almost discussing the performers as fiction as well). This discourse provoked those who disagreed, for example, the educator and disability activist Robert Bogdan. In his book Freak Show: Presenting 'Human Oddities'for Amusement and Profit (1988), he makes an attempt to understand his own fascination for - as he calls them - human oddities and blames Fiedler for mystifying instead of de-mystifying the people staging the freaks in the sideshow settings:

“[Fiedler's] mythological, psychoanalytical approach posits that human beings have a deep, psychic fear of people with specific abnormalities. (...) His typology of human oddities does not stray from the traditional view of 'freak' as a physiological condition, and it excludes exhibits with no physical anomalies. Thus, rather than penetrating the socially constructed dimension of the freak show, he merely mystifies it" (BoGDAN 1988:7).

Bogdan, then a professor at the School of Education at Syracuse University, departed from observations he had made about movies, particularly in the horror genre where disability was to him directly connected to representations of evil. Looking at material obtained from circus archives, Bogdan observes: "Our reaction to freaks is not a function of some deep-seated fear or some energy that they give off; it is, rather, the result of our socialization and of the way our social institutions managed these people's identities" (BoGDAN 1988:X). He had moved from Fiedler's mythological construction that perceives freaks in their exposed role as fearful constructions catering to basic human needs to discuss the idea of the freak as a social construct.

In his conclusion, he insists again that he did not intend to exoticize or enfreak people (which he accuses Fiedler of doing) but wanted to (and did) look at the exhibition of freaks as an institution that mirrors the concerns of its time. This he explores best when looking at ethnographic exhibits or at gender. His chapter on the exhibition of "Cannibals and Savages" ends with a critical thought on the American context of such displays. Bogdan concludes that Americans "did not confront their own ethnocentrism. On the contrary, what they saw merely confirmed old prejudices and beliefs regarding the separateness of the 'enlightened' and 'primitive' worlds" (BoGDAN 1988:197). He continues to point out that the ethnic exhibit helped to exploit the non-Western world and implanted racist attitudes that perpetuated the unequal treatment of nonwhites (BoGDAN 1988:197). While he does not make a reference to Said, he makes the same argument, namely that colonial attitudes needed to be confirmed by staging the other in absolute contrast to the self.

However, Bogdan also looks at the constructions of gender when he talks about the exhibition of tattooed women that became popular from the 1880s onwards, particularly, he argues, because to show their tattoos, the women had to "expose parts of their bodies - their legs and thighs - which under any circumstances would have been lewd if not illegal" (BoGDAN 1988:251). He also discusses the tension between what women were supposed to be: "chaste, docile, and inconspicuous - and what the tattoos had come to stand for - criminality, flamboyance, and decadence" (BoGDAN 1988:251). Yet, he does not question the staged role of women or provide a feminist reading. As in the case of the 
ethnic other, Bogdan's approach is rather practical, categorizing and sharing observations rather than analyzing them. To him, everything is evidence of the maltreatment and marginalization of people with other/ed bodies.

In case of performers with visible disabilities, Bogdan attempts not to follow the usual medical categorization. Instead, he looks at the 'profiles of presentation'. Thus, he juxtaposes presentations of grandeur, by which he means an exaggerated manner to connect the extraordinary to the royal, to the respectable. In the latter category, he discusses people such as the conjoined twins Chang and Eng, whom he perceives to be modest and whose exhibition narrative Bogdan understands as mainly providing a glimpse into an ordinary life. In this chapter, he also looks at the staging of marriages as a normative institution that helped the performers gain social status, mainly because nonnormative bodies engaging in relationships like everyone else was unexpected.

Bogdan continued to look at visual materials of people with non-normative bodies, particularly photographs. A collection of photographs from the archives (and his own collection) was published in 2012 (Picturing Disability), in which Bogdan shows the variety of genres of photography of which the carte-de-visite was only one among many. While he did not analyze the photographs, he managed to provide a wide range of modes of representation of people with disabilities, making material available that may be helpful for further research, even though literature on medical photographs in the form of a coffee table book (LINDGREN 2007), on beggar cards as a scholarly investigation (SCHWEIK 2009), and, of course, on side show souvenir cards as published collections (VoIGT 2006) already exists and is added to by artists such as Diana Arbus who also worked on the othered body (ISRAEL - ARBUS 2012). All genres of photographs document different discourses around disability that often intersect. For example, the medical/scientific discourse vividly joins the sensational and popular discourse of freak show presentations (STAMMBERGER 2011). After all, Bogdan's photobook is another coffee table book that may provoke the sensationalism that he, even in his previous works, denounces enthusiastically.

A more substantial work concerning the analysis of disability and representation is Sander Gilman's Disease and Representation that, like Bogdan's book on freak shows, was published first in 1988. Like Fiedler and Said, Gilman was a professor of (German) literature (at Cornell University at the time of the book's publication), but he was also a professor of the History of Psychiatry (at Cornell Medical College). His book vividly reveals the intersection of both fields while looking at the aesthetic tradition of visual depictions of diseases.

\footnotetext{
"It is indeed the social implications of the construction of stereotypes of disease, society's image of the patient as well as the internalized response of the patient, which is the reason for any study of these structures of perception and representation. In this book [Disease and Representation] our ongoing attempt to categorize (and, therefore, to distance) ourselves from those we label as different (and their response) will be examined" (SANDER 1988:17).
}

This argument is closer to Said than it is to Bogdan, as Gilman tries to understand the modes of staging otherness in images throughout the centuries. Most of the material analyzed in the book concerns mental diseases and conceptions of madness, but Gilman also includes a chapter on medical colonialism before he continues to observe the 
connection between mental diagnosis and sexuality, finishing with a chapter on AIDS and placing his study in the heart of the AIDS crisis in the United States. In his previous book, Difference and Pathology (GILman 1985), Gilman had analyzed stereotypes of race and sexuality and their relationship to discourses of madness (which is non-normativity in general in this case). This narrative also includes a chapter about the exhibition of Sarah Baartman as the Hottentot Venus called "The Hottentot and the Prostitute: Toward an Iconography of Female Sexuality". ${ }^{8}$ Gilman discusses the contradiction in the exhibition of Sarah Baartman between the placing of the racial other and female sexuality, revealing the freak show discourse not only as a performance of the male gaze (a fact that Bogdan pointed out with the discussion of tattooed women) but also as an imperial activity that justified the suppression of the (particularly racial/ethnic) other: "The labels given outsider groups are legion. One of the most fascinating is that of 'race.' In 'seeing' (constructing a representational system for) the Other, we search for anatomical signs of difference such as physiognomy and skin color" (GILMAN 1985:25).

While this is before the introduction of the concept of intersectionality, ${ }^{9}$ Gilman succeeds in combining race and gender in the case of Sarah Baartman, showing how the concepts intersect to stage her othered body. Her case sparked numerous works (such as her biography, see CRAIS - SCULlY 2009), but Gilman was the first to attempt an analysis of the popularity of her case, which also took the analysis of the freak show to an entirely different level because it allowed for questions about the legacy of the freak show performers. ${ }^{10}$

\section{THE 1990S - OTHERED EYES THAT LOOK BACK}

In 1994, Disability Studies was introduced as an academic discipline at Syracuse University. Only two years later, the very influential essay collection Freakery, edited by Rosemarie Garland-Thomson, was published (GARLAND-THOMSON 1996). The Foreword is written by Fiedler, who understands his book about the secret self as a breakthrough. $\mathrm{He}$ writes immodestly that he is "pleased to have contributed to making such studies of popular culture like Freakery not only possible but integral to cultural studies" (FIEDLER 1996:xvi), a field he claims to have enabled with his earlier work. However, Garland-Thomson refers to Bogdan, not Fiedler, as the source that inspired her work on extraordinary bodies. Freakery seeks "to reveal the practices and cultural logic that constructs certain corporeal variations as deviant and to denaturalize the generally assumed opposition between normal and abnormal bodies", she writes (Garland-THOmson

8 Fiedler and Bogdan also mention Sarah Baartman briefly. Bogdan writes in general about the exhibition of Hottentots (BoGDAN 1988:187), while Fiedler mentions her in connection to exoticized eroticism (FIEDLER 1978:141-43).

9 The concept of intersectionality appears in the poems and essays of Audre Lorde in which she addresses her own intersections of being a woman, black, and homosexual (LORDE 2000; 2007), and in the context of black feminism theorized in the 1980s by bell hooks (1984). Intersectionality looks at the multiple dimensions of discrimination evident when several categories of marginalized identities apply.

10 Baartman's remains were on exhibit in the Musée de l'Homme (Paris, France) until the 1970s and then kept in the museum until they were successfully repatriated to South Africa in 2002. 
1996:xviii). The freak of nature, she claims, is indeed a freak of culture, not that Fiedler or Bogdan would disagree. The problem with this argument is its ultimate need to be placed within a framework of a particular place and time. While the previously discussed works did not think of themselves as particularly American (though they were), the freak show becomes an American phenomenon in Garland-Thomson's eyes:

\footnotetext{
"Especially in Victorian America, the exhibition of freaks exploded into a public ritual that bonded a sundering polity together in the collective act of looking. In a turbulent era of social and material change, the spectacle of the extraordinary body stimulated curiosity, ignited speculation, provoked titillation, furnished novelty, filled coffers, confirmed commonality, and certified national identity" (GARLAND-THOMSON 1996a:4).
}

This reading of the phenomenon quite obviously ignores the transnational dimensions of the freak show and the international fame of the performers. However, the individual essays speak to the different national contexts of the freak show. An essay by Paul Semonin (1996) looks at freaks in early modern England, and Nigel Rothfels (1996) discusses examples of exhibitions in Germany. However, none of the essays deals with Central or Eastern Europe, although many of the performers traveled and performed in countries other than England, Germany, and the United States (see, e.g., Kopania in the present volume).

As a literary scholar, Fiedler had diagnosed the freak in literature as an American phenomenon in which authors fashion characters they as outcasts themselves feel connected to (FIEDLER 1978:285). In particular, he mentions the work of Flannery O'Connor that he connects to the self-hatred of the Southern States after their defeat in the Civil War at the end of the $19^{\text {th }}$ century (FIEDLER 1978:285). Furthermore, he understands the freak as a symptom of guilt in the works of Günther Grass that emerged after World War II (FIEDLER 1978:285) and carefully reduces his study to the Western world. Bogdan, who focusses on the circus as a form of expression, states that "midnineteenth-century America provided the ideal venue for humbug to be institutionalized as a fine art and as a basic and lasting part of the freak show" (BoGDAN 1988:31). He then refers to P. T. Barnum.

While those earlier works portray 'freakery' as a general human phenomenon (in the Western world), Garland-Thomson's collection makes the North American focus obvious and reveals the Anglo-centrism of the understanding of the staging of othered bodies. Furthermore, the essay collection departs from looking merely at modes of representations to discuss examples in the framework of queer theory and feminism (Grosz 1996) as well as the medical humanities (RothFels 1996). As such, the book was groundbreaking also in looking at corporealities used by the freak show scenario to twist the understanding of phenomena taken for granted (such as gender) and paved the way for interdisciplinary conversations. However, the actual national contexts and places are no longer questioned, which complicates the theory twist because it - again institutionalizes corporeal phenomena as universal.

Garland-Thomson's monograph published a year later, called Extraordinary Bodies (1997), focuses on the gap "between disabled figures as fashioned corporeal others whose bodies carry social meaning and actual people with atypical bodies in real-world social relations" (GARLAND-THOMSON 1997:15). Garland-Thomson saw her book as a 
manifesto that would institutionalize Disability Studies within the humanities. But, as in many such identity study attempts, the complaint of difference or othering is a strategic one that enables the argument in the first place and strengthens the difference instead of overcoming the dichotomic understanding of the subject or offering alternative readings. This argument peaks in the claim that only disabled authors should talk about disability, bringing back the author we had thought dead for a long time and connecting the ability to create fiction to real life experiences. Instead of enriching the canon, the consequence is an alternative canon that creates categories in the bookstore that still seem to claim that a category of universal fiction (that continues to be written mainly by white able-bodied heteronormative men) exists and that authors who are different in some way from them can only write about their own experiences.

On the other hand, Garland-Thomson's work succeeded in introducing the agency of the othered bodies. The pitiful gaze that was employed in earlier literature (such as by Scheugl and Bogdan) is a well-meaning attempt to reveal mechanisms of exploitation while it denies agency from the freak show performers. They were seen as helpless victims and not as active negotiators of the conditions of their contracts. This was not always the case, of course, and yet the possibility of an active participation in the capitalist agenda of fame and fortune cannot be denied. Garland-Thomson shows that in the $19^{\text {th }}$-century forms of representation (be it literature or show material), the performers are presented without agency, and an uncritical reading of that representation leads to the wrong conclusions. The dynamics of the gaze may be humiliating at times but they can also be empowering. ${ }^{11}$

\section{THE 2000S - THE FREAK SHOW CONTINUES}

This shift from object to subject also marks Rachel Adams' fundamental analysis of freaks in the American cultural imagination. "Freaks represent themselves as radically individuated subjects when in fact they are the products of sustained collaborations", she states right at the beginning of her book Sideshow U.S.A. (ADAms 2001:ix). She begins her work with the analysis of the ethnographic other, placing it, like Gilman did, within the framework of race in the United States. Adams looks at exhibits that used people with and without disabilities to narrate the primitive other in order to project fantasies of dominion and superiority. She also shows the continuity of the freak show as it changes medium, discussing film, literature, and photography as forms in which the freak show continues to live on. She does not mean to say that those forms are new forms of the freak show, but rather to show how the $19^{\text {th }}$-century freak show act continues to live on in these forms. In her chapters on whiteness as well as on motherhood, she reveals how the freak show acts have not disappeared but continue to be staged in their very same form as they had been one hundred years ago.

${ }_{11}$ The idea of the gaze became a tool of academic analysis with (institutionalized) feminism. Film scholar E. Ann Kaplan published her book on the gaze in 1997 thinking about ways of othering in a postcolonial context (KAPLAN 1997). Garland-Thomson's book On Staring came out in print in 2009. Again, both books talk about ways of exoticizing and exposing, but while Kaplan looks at the overall scheme in the cinematic gaze, Garland-Thomson personalizes and individualizes the account within the framework of disability studies. 
But not only does the freak show haunt Adams' book, Fiedler and his reading of freaks also makes a reappearance: "The problem with an exclusively psychoanalytic account of freaks is that it threatens to universalize phenomena that are historically and culturally variable, and to appropriate the details of individual lives as effects of authorial subjectivity", writes Adams in reference to Fiedler (ADAMs 2001:8). Further on in the book, she fires at Fiedler's sexual obsession with freaks, saying that "his notion that all human eroticism is founded on an attraction of opposites - the more different, the more forbidden and passionate the attraction - is implicitly heterosexual. (...) Indeed, his entire description of freaks' sexual appeal presupposes not only a heterosexual but a masculine sensibility" (ADAMS 2001:152). She continues to read Fiedler's book as an autobiographical response to the 1960 s and an attempt to cope with the newly unsettled identity of its author who had proudly understood himself as part of a rebellious subculture and now feels threatened by those that emerge as such.

Adams' focus on the United States is not a move that narrows the scope of the discussion. Rather, it admits that the research and analysis come from a specific perspective and can only look at a specific area (and time) that is in this case marked geographically (and consequently culturally). Publications like hers showed that the freak show had transitioned from being a (often sensationalized) case study to becoming a tool to understand concepts such as the nation. In her book Never One Nation, Linda Frost looks at the shifting idea of whiteness using the exhibit of the Circassian Beauty in $19^{\text {th }}$-century America to discuss the entanglement of race, class, and sexuality (FrOST 2005). While she carefully contextualizes images within the American history of the tension between North and South, she sees the success of the Circassian Beauty in a more generalized way, understanding her as a construct of a patriarchal controlling domestic ideology: "[T]he Circassian Beauty embodies a sensual pleasure and sexual power that, in the harem of Western myth, would have marked her value" (Frost 2005: 81). In fact, the performance act of the Circassian Beauty appeared shortly after the American Civil War in 1864 as part of P. T. Barnum's entertainment empire, and thus is an act that can be read true to the American context as it also employs the topic of slavery. While situated within the historical context of its subject, the reading of Frost's work obviously addresses contemporary issues of American racism.

Similarly, the Californian English professor Susan Schweik analyzed the "unsightly beggar", who is banned from American streets during the $19^{\text {th }}$ century due to his/her body being visually disturbing, in her book The Ugly Laws (SCHWEIK 2009). It is a different display of bodies not unlike the freak show but obviously less connected to the entertainment industry and its glamour and fame. The book is concerned with the emergence of the 'ugly laws' in different states of the United States that eventually allow a persecution of disabled people begging in public, also looking at the material they sell such as autobiographical narratives and images. Her book addresses crucial issues such as the body in public spaces and the connection between law and language based on a close, almost poetic, reading of the texts involved in the debates. Schweik also shows the shift in literary studies. As she is focused on texts, she also interviews people, including contemporary disability activists, to contextualize her work and to avoid a purely aesthetic framing as her book really is about "the discursive unsightly beggar" (ScHWEIK 2009:viii). Again, a shift in the possibilities of literary studies can be seen. While Fiedler marked the shift from canonic literature to popular materials, Schweik 
takes a variety of materials such as laws and popular pamphlets into account and uses both alike to make her point.

In 2012, the perspective shifted again to finally enter a transnational scope with Cynthia Wu's study Chang and Eng Reconnected. While the transnational twist has been diagnosed - at least within American Studies since the 1990s - monographs that applied that approach, particularly in the context of othered bodies, took some time to appear. By its title, the book suggests a revisiting of the conjoined twins from Siam who became celebrities in the $19^{\text {th }}$ century. Brought to the United States for their extraordinary body, the brothers appeared at sideshows around the world before they settled on a farm to live a middle-class life in North Carolina. Due to their fame, Chang and Eng have been mentioned in most of the above works (Gilman being the exception). However, Wu does not attempt to historicize or personalize the twins' experience or examine their particular condition but to undertake a much larger project: she aims to "reveal how dimensions of power operate within American cultures by providing a transhistorical analysis of materials from the nineteenth, twentieth, and early twenty-first centuries that feature the Bunkers" (Wu 2012:2). Thus, she combines Disability Studies, Asian American Studies, as well as literary criticism, cultural theory, and anthropology. Wu looks at the re-surfacing of the twins as Adams had looked at the resurfacing of the freak show. She also no longer speaks of one American context but reveals with the plural cultures that the transnational context is always already given. Yet it does not explain the long absence of Eastern European and other cultural and national discourses from the field. Luckily, this is changing. In 2016, Dagnosław Demski launched the project Staged Otherness. Human Oddities in Central and Eastern Europe, 1850-1939 that allows for substantial research in the field. ${ }^{12}$ Other geographical areas such as the Middle East or Asia are yet to follow.

\section{CONCLUSION: THE AMERICAN FREAK SHOW}

In 2014, the extremely popular mainstream television series American Horror Story launched its fourth season called Freak Show. It follows a circus sideshow in the 1950s in a small town in Florida whose director Elsa Mars tries to save the freak show format against all odds and its shrinking popularity. The town is haunted by a serial killer whom the series portrays as the actual freak, whereas the circus performers, similarly to Tod Browning's vision in 1932, are portrayed in their scope of human relationships in the range of emotional extremes. Their seemingly cruel director turns out to have been mutilated by sadists in Germany, a fact that connects the seemingly normative-looking woman to her employees in the show. Again, the transnational component is Germany and its war history. It seems that Scheugl's point about the Nazis is repeated here. The real freak, the series seems to suggest, is not the one who looks like one. In fact, the freak performers live in constant danger of being accused of crimes they did not commit or turned into profit by evil agents that do not hesitate to bargain with their life in order

12 The project is entitled Inscenizowana inność. Ludzkie odmienności w Europie Środkowej, 18501939 (Staged Otherness. Human Oddities in Central and Eastern Europe, 1850-1939); the research is funded by the National Science Center Grant No. UMO-2015/19/B/HS3/02143. 
to collect the physical remains. When read as a reference to Browning's Freaks, the narrative seems to say that nothing changed in 1952 (the time of the story) or, as a matter of fact, now. But framing the series as American (with its title and with the setting of the narrative), once again the freak show remains to be owned in its simplified version by the American mainstream. The transnational interaction as well as counter-narratives never enter the American public and academic discourse. ${ }^{13}$

I would like to conclude with Margrit Shildrick's approach to disability that she exposes in her text Dangerous Discourses of Disability, Subjectivity and Sexuality (SHILDRICK 2009). Shildrick uses feminist and queer theory in an attempt to situate disability productively in our contemporary society. Shildrick, who had looked at early modern concepts of monstrosity in one of her previous books (SHILDRICK 2002), tries to trace the binary of self and other that seems to be omnipresent in discussions of such adventures as freak shows or ethnic shows. But what she is really getting at is the concept of identity studies as it continues to spread, the identification with "one category rather than the other" that is "seen as a source of strength" (SHILDRICK 2009:6). Thus, she criticizes the so-called standpoint theory at the heart of Postcolonial and Disability Studies which "openly privileges the lived experience and knowledge of those at the centre of the problematic" (SHILDRICK 2009:9). This is, of course, as Shildrick argues, understandable from a historical point of view, since their voices have been silenced. However, following Michel Foucault, we know that power constructs truth and any claim of it, from whichever perspective needs to be distrusted (FouCAULT 1980). Shildrick aims at a re-theorization of the question of difference. She tries to bridge the gap constructed in the setting of self and other/performer and audience by arguing for the necessity of understanding the entanglement rather than its opposing forces. Bodies in a room respond to each other. The show formats reveal one thing - the instability of categories and the traps our scholarship has prepared for us - to identify the dynamics of non-definable bodies, we need to categorize and rewrite the boundaries that we intend to unwrite.

\footnotetext{
"Regardless of how modernist binaries may be deconstructed, regardless of how unstable their bare understanding of oppositional difference, they cannot be simply dismissed: their power may be based on an illusion, but its operation is all too real. What matters is that we do not mistake the challenge to the effects of binary opposition as the limit of what is possible and necessary" (SHILDRICK 2009:3).
}

Within that framework, the international entanglements of the freak show provide a point of departure, because it will allow us to look beyond the assumption that audiences are unified by the shows. It will allow us to understand the dynamics of sources and languages that play a crucial role in our scholarship as they played a role in the internal marketing strategies of the shows. Rather than documenting the difference, it will be the similarities that can question the notion of an American cultural imagination. Beyond the binaries of self and other, the question remains why the shows worked on both sides of the ocean, in different political systems and urban and non-urban contexts. While this does not

13 Such a counter-narrative (in the sense of a different story about othered bodies) is Tatyana Tolstaya's novel The Slynx (2007). Set in a post-nuclear totalitarian setting, physical mutations are not the exception but the norm, creating a dystopian scenery. 
come as a surprise when thinking about celebrity culture, it needs to be contextualized within the framework of othered bodies whose appeal was in the exhibition of physical difference that was meaningful to more than just American audiences.

\section{REFERENCES CITED}

ADAMs, Rachel

2001 Sideshow U.S.A. Freaks and the American Cultural Imagination. Chicago: University of Chicago Press.

Altick, Richard

1978 The Shows of London: A Panoramic History of Exhibitions, 1699-1862. London: Belkamp.

Assmann, Jan - Assman, Aleida

1992 Das kulturelle Gedächtnis. Schrift, Erinnerung und politische Identität in frühen Hochkulturen. München: C.H. Beck.

BogDan, Robert

1988 Freak Show. Presenting Human Oddities for Amusement and Profit. Chicago: University of Chicago Press.

2012 Picturing Disability. Beggar, Freak, Citizen, and Other Photographic Rhetoric. Syracuse, NY: Syracuse University Press.

Cook, James W. (ed.)

2005 The Colossal P. T. Barnum Reader. Urbana and Chicago: University of Illinois Press.

Crais, Clifton - Scully, Pamela

2009 Sara Baartman and the Hottentot Venus: A Ghost Story and a Biography. Princeton, NJ: Princeton University Press.

DAVIES, Helen

2015 Neo-Victorian Freakery. The Cultural Afterlife of the Victorian Freak Show. New York: Palgrave Macmillan.

DRIMMER, Frederick

1973 Very Special People. The Struggles, Loves, and Triumphs of Human Oddities. New York: Amjon Publishers.

DurbaCH, Nadja

2009 Spectacles of Deformity. Freak Shows and Modern British Culture. University of California Press.

FANON, Frantz

1963 The Wretched of the Earth. New York: Grove Weidenfeld.

FIEDLER, Leslie

1978 Myth and Images of the Secret Selves. New York: Simon and Schuster.

1996 Foreword. In GARLAND-ThOMSON, Rosemarie (ed.) Freakery. Cultural Spectacles of the Extraordinary Body, XIII-XVI. New York: New York University Press.

Foucault, Michel

1980 Power/Knowledge. Selected Interviews and Other Writings 1972-1977. Brighton: Harvester Press. 
Frost, Linda

2005 Never One Nation. Freaks, Savages, and Whiteness in U.S. Popular Culture 1850-1877. Minneapolis: University of Minnesota Press.

GARLAND-THOMSON, Rosemarie

1996 Introduction: From Wonder to Error - A Genealogy of Freak Discourse in Modernity. In Garland-Thomson, Rosemarie (ed.) Freakery. Cultural Spectacles of the Extraordinary Body, 1-19. New York: New York University Press.

1997 Extraordinary Bodies. Figuring Physical Disability in American Culture and Literature. New York: Columbia University Press.

2009 Staring. How We Look. Oxford: Oxford University Press.

Garland-Thomson, Rosemarie (ed.)

1996 Freakery. Cultural Spectacles of the Extraordinary Body. New York: New York University Press.

Gilman, Sander L.

1985 Difference and Pathology. Stereotypes of Sexuality, Race, and Madness. Ithaca and London: Cornell University Press.

1988 Disease and Representation. Images of Illness from Madness to AIDS. Ithaca and London: Cornell University Press.

Gould, George M. - PyLE, Walter L.

1896 Anomalies and Curiosities of Medicine. Volume 1 \& 2. New York: Bell Publishing Company.

Grosz, Elizabeth

1996 Intolerable Ambiguity: Freaks as/at the Limit. In GARLAND-ThOMSON, Rosemarie (ed.) Freakery. Cultural Spectacles of the Extraordinary Body, 55-66. New York: New York University Press.

HARTZMAN, Marc

2005 American Sideshow. An Encyclopedia of History's Most Wondrous and Curiously Strange Performers. New York: Penguin.

HAWKINS, Joan

1996 'One of Us': Tod Browning's Freaks. In Garland-Thomson, Rosemarie (ed.) Freakery. Cultural Spectacles of the Extraordinary Body, 265-276. New York: New York University Press.

Hooks, Bell

1984 Feminist Theory. From Margins to Center. Cambridge, MA: South End Press. ISRAEL, Marvin - Arbus, Doon

2012 Diane Arbus. An Aperture Monograph: Fortieth Anniversary. New York: Aperture.

KaPlan, Ann E.

1997 Looking for the Other: Feminism, Film and the Imperial Gaze: Nation, Woman and Desire in Film. New York: Routledge.

KÉRCHY, Anna - ZITTLAU, Andrea

2012 Exploring the Cultural History of Continental European Freak Shows and 'Enfreakment'. Newcastle upon Tyne: Cambridge Scholars Publishing. 


\section{KLEE, Ernst}

1983 "Euthanasie" im Dritten Reich. Die Vernichtung Lebensunwerten Lebens. Frankfurt am Main: Fischer.

KopaniA, Izabela

2019 In the Footsteps of Julia Pastrana. Cultural Responses to an Ape-woman's Stay in Warsaw in 1858 and Reaction of Polish Press to Her Extraordinary Body. In the present volume.

Koren, Yehuda - NeGEv, Eilat

2005 In Our Hearts We Were Giants. The Remarkable Story of the Lilliput TroupeA Dwarf's Family's Survival of the Holocaust. Boston, MA: Da Capo Press.

LINDGREN, Laura

2007 Mütter Museum. Historic Medical Photographs. Philadelphia: Blast Books.

LORDE, Audre

2000 The Collected Poems of Audre Lorde. New York: Norton.

2007 Sister Outsider. Essays and Speeches. Toronto: Crossing Press.

RobBins, Tod

1923 Spurs. The Story of Jacques Courbe, the Dwarf of Copo's Circus, and Jeanne Marie, Bareback Rider. Munsey's Magazine 78(1): 24-32.

RoTHFELS, Nigel

1996 Aztecs, Aborigines, and Ape-People: Science and Freaks in Germany, 1850 1900. In Garland-Thomson, Rosemarie (ed.) Freakery. Cultural Spectacles of the Extraordinary Body, 158-172. New York: New York University Press.

SAID, Edward

1978 Orientalism. New York: Vintage Books.

2003 Orientalism. $2^{\text {nd }}$ ed. London: Penguin.

SCHEUGL, Hans

1974 Show Freaks and Monsters. Sammlung Felix Adanos. Köln: Du Mont Verlag.

ScHWEIK, Susan M.

2009 The Ugly Laws. Disability in Public. New York: New York University Press.

SEMONIN, Paul

1996 Monsters in the Marketplace: The Exhibition of Human Oddities in Early Modern England. In Garland-Thomson, Rosemarie (ed.) Freakery. Cultural Spectacles of the Extraordinary Body, 69-81. New York: New York University Press.

SHILDRICK, Margrit

2002 Embodying the Monster. Encounters with the Vulnerable Self. London: Sage.

2009 Dangerous Discourses of Disability, Subjectivity and Sexuality. New York: Palgrave Macmillan.

STAMMBERGER, Birgit

2011 Monster und Freaks. Eine Wissensgeschichte außergewöhnlicher Körper im 19. Jahrhundert. Bielefeld: Transcript Verlag.

Thode-Arora, Hilke

1989 Für fünfzig Pfennig um die Welt. Frankfurt am Main: Campus Verlag.

TOLSTAYA, Tatyana

2007 The Slynx. New York: NYBR. 
TROMP, Marlene.

2008 Victorian Freaks. The Social Context of Freakery in Britain. Ohio State University Press.

VEBLEN, Thorstein

1899 The Theory of Leisure Class. An Economic Study in the Evolution of Institutions. New York: Macmillan Co.

VoIGT, Jochen

2006 Faszination Sammeln. Cartes de Visite: Eine Kulturgeschichte der photographischen Visitenkarte. Chemnitz: Edition Mobiles.

Wu, Cynthia

2012 Chang and Eng Reconnected. The Original Siamese Twins in American Culture. Philadelphia: Temple University Press.

ZitTLAU, Andrea

2017 The Freak-Show Act. Science and Spectacle in the Nineteenth Century. In Hanes, Roy - Brown, Ivan - Hansen, Nancy E. (eds.) The Routledge History of Disability, 381-393. London and New York: Routledge.

Andrea Zittlau teaches in the English Department of the University of Rostock, Germany and focuses on the body, performance art, poetry, and experimental film in her research and writing. Her recent publications include an essay in The Routledge History of Disability (2017) on the freak show as performance art and an anthology of poetry by incarcerated men (edited with Jayne Thompson. N.I.G.H.T. Poetry by Incarcerated Men. Pink Gorilla Press, 2016). E-mail: andrea.zittlau@uni-rostock.de 